\title{
PENGARUH FAKTOR FUNDAMENTAL KEUANGAN TERHADAP BETA SAHAM PADA PERUSAHAAN MANUFAKTUR YANG GO PUBLIK DI BURSA EFEK INDONESIA
}

\author{
Jhony Fahrin Sapar \\ Sekolah Tinggi Ilmu Ekonomi Pancasetia Banjarmasin \\ J1. A Yani Km. 5,5 Banjarmasin, Kalimantan Selatan \\ e-mail: jhonyfahrinsapar@gmail.com
}

\begin{abstract}
This research is intended to find out the influence of financial fundamental factors that consisted by debt to equity leverage, liquidity, asset size, and asset growth, toward stocks beta value. This research is done to 30 manufacturing company listed on Jakarta's stock exchange between 2004 until 2011 periods. This research used secondary data in form of companies' financial report, individual stock price index, and manufacture company stock index. Method for analysis used is linear multiple regression. The finding of this research showed that debt to equity, leverage, liquidity, asset size, and asset growth did not have a significant influence to stock price. It means all of five variables did not have any impact toward the movement of stock beta value.
\end{abstract}

Keywords: debt to common equity, leverage, liquidity, asset size, asset growth, beta stock value

\begin{abstract}
Abstrak: Penelitian ini bertujuan untuk mencari pengaruh faktor fundamental keuangan yang terdiri dari debt to common equity, leverage, likuiditas, asset size, dan asset growth terhadap nilai beta saham. Penelitian dilakukan pada 30 perusahaan manufaktur yang listing di Bursa Efek Jakarta dengan periode penelitian dari tahun 2004 sampai dengan tahun 2011. Penelitian ini menggunakan data sekunder laporan keuangan perusahaan, harga indeks saham individual dan harga indeks saham manufaktur. Metode analisis yang digunakan adalah analisis regeresi Linear berganda. Temuan dari penelitian ini menunjukkan bahwa debt to common equity, leverage, likuiditas, asset size, dan asset growth secara simultan tidak berpengaruh signifikan terhadap nilai beta saham. Ini artinya kelima variabel tersebut tidak memberikan dampak terhadap pergerakan nilai beta saham.
\end{abstract}

Kata Kunci: debt to common equity, leverage, likuiditas, asset size, asset growth, nilai beta saham

\section{Latar Belakang}

Pasar modal merupakan sarana perusahaan untuk memenuhi kebutuhan dana jangka panjang dengan menjual saham atau mengeluarkan obligasi. Sedangkan bagi para investor, pasar modal merupakan sarana untuk menginvestasikan kelebihan dana yang mereka punyai dengan harapan memperoleh return yang lebih besar dari jumlah yang telah diinvestasikan. Di antara beberapa instrumen surat berharga di pasar modal, saham merupakan salah satu surat berharga yang paling banyak diminati oleh para investor karena saham dapat memberikan return yang lebih tinggi dibanding surat berharga lainnya. Seperti dua sisi mata uang yang tidak dapat dipisahkan, selain memberikan return yang tinggi, saham perusahaan yang go-publik sebagai komoditi investasi tergolong beresiko tinggi. Sifat komoditinya sangat peka terhadap perubahan-perubahan yang terjadi, baik perubahan di luar negeri maupun di dalam negeri, perubahan di bidang politik, ekonomi, moneter, undang-undang, maupun perubahan yang terjadi di dalam industri dan perusahan itu sendiri. Sebagai sumber 
informasi bagi konsumen pasar modal mengenai harga saham, setiap kurun waktu tertentu Bursa Efek Indonesia mengeluarkan informasi mengenai beberapa indeks saham yang diperdagangkan yaitu Indeks Harga Saham Gabungan (IHSG) atau dikenal pula dengan istilah composite index, Indeks sektoral, Indeks LQ 45, dan Jakarta Islamic Index (JII).

Kejadian atau isu yang negatif membuat harga-harga saham secara umum turun, sebaiknya kejadian atau isu positif membuat harga-harga saham secara bersama-sama mengalami kenaikan. Namun demikian respon masing-masing saham terhadap suatu peristiwa tidak sama. Pergerakan harga saham terjadi sangat cepat dan sangat dipengaruhi oleh beberapa faktor seperti kondisi politik dan ekonomi suatu negara selain juga tentunya dipengaruhi oleh faktor fundamentalnya. Besarnya fluktuasi Indeks Harga Saham Gabungan, diukur dengan koefesien beta (ß) dari saham tersebut. Menurut teori CAPM, beta merupakan ukuran yang cocok untuk resiko saham yang relevan. Nilai koefisien beta yang besar menunjukan tingkat kerentanan yang tinggi dibanding beta yang kecil. Artinya pergerakan harga saham yang berbeta besar lebih berfluktuasi dibanding saham yang berbeta kecil. Beta merupakan ukuran resiko eksternal yang disebabkan oleh faktor-faktor eksternal (resiko sistematis).

Harga-harga saham di Bursa Efek Indonesia sangat berfluktuasi sebagai respon dari kejadian-kejadian dan isu-isu ekonomi dan politik yang terjadi di dalam maupun luar negeri. Krisis ekonomi yang melanda Indonesia pada tahun 1997 merupak krisis regional yang juga melanda sebagian besar negara-negara di Asia Tenggara. Mata uang rupiah terdevaluasi lebih dari 40\%. Bahkan saat kondisi perpolitikan Indonesia semakin parah, terjadi demonstrasi kepada penguasa politik dan kerusuhan besar-besaran terjadi di Jakarta pada tahun 1998 lalu, rupiah melemah sampai melewati lebih dari Rp 10.000 per satu dolar Amerika. Efek krisis tersebut juga melanda pasar modal Indonesia. Dalam tempo kurang dari 14 bulan, Indeks Harga Saham Gabungan atau IHSG di Bursa Efek Indonesia turun lebih dari $14.31 \%$. Demonstrasi dan kerusuhan di tahun 1998 menyebabkan anjloknya harga saham, sementara pemilu yang sukses di tahun 1999 ikut mendongkrak naik pergerakan harga saham, sementara di penghujung tahun 2007 IHSG begitu fluktuatif terpengaruh oleh kondisi ekonomi internasional. Setelah pasar modal RI anjlok karena dampak resesi subprime mortgage, hanya dalam waktu satu bulan IHSG kembali berkibar karena dipicu oleh naiknya bursa regional sebagai respon positif terhadap penurunan suku bunga oleh bank sentral Amerika, The Federal Reserve. Krisis keuangan global yang terjadi ditahun 2008, yang dimulai dari Amerika, kembali membuat harga saham bergejolak, berbeda dengan dari krisis keuangan tahun 1997 yang berdampak lokal, krisis 2008 meluas hampir ke seluruh dunia, bursa saham berjatuhan, perusahaanperusahaan multinasional bangkrut, banyak perusahaan di Amerika Serikat yang melakukan pengurangan tenaga kerja, para investor portofolio di bursa saham menarik dananya, akibatnya bursa saham rontok, Bursa Saham Indonesia melakukan penghentian sementara perdagangan saham karena penurunan indeks yang terlalu besar, mencapai $10,38 \%$, Indeks harga saham gabungan (IHSG) turun tajam sebesar 168,052 poin dan indeks LQ 45 terkoreksi 38,361 atau $11,86 \%$, sedangkan nilai rupiah terhadap dolar sempat mencapai level $\mathrm{Rp}$. 12.000,- per USD 1.

Beberapa fakta di atas menunjukan betapa rentannya harga saham di Bursa Efek Indonesia terhadap kondisi pasar atau betapa besarnya pengaruh faktor eksternal terhadap harga saham tersebut. Besarnya fluktuasi Indeks Harga Saham Gabungan (IHSG) diukur dengan koefesien beta (B) dari saham tersebut. Nilai koefesien beta yang besar menunjukan tingkat kerentanan yang tinggi dibanding beta yang kecil. Artinya pergerakan harga saham yang berbeta besar lebih berfluktuasi dibanding saham yang berbeta kecil. Beta merupakan ukuran resiko eksternal yang disebabkan oleh faktor-faktor eksternal (resiko sistematis), sementara dari beberapa sumber teoritis dan kajian empirik ditemukan bahwa selain dipengaruhi oleh faktor-faktor eksternal, nilai beta ternyata secara signifikan juga dipengaruhi oleh faktor fundamental 
keuangan perusahaan. Beaver $\mathrm{Cs}$, meniliti tentang hubungan antara variabel fundamental keuangan dengan beta pasar, variabel yang diteliti adalah deviden pay out, asset growth, leverage, liquidity, asset size, earning variability, dan accounting beta, dari hasil penelitian variabel dividen pay out, leverage, earning variabilty, dan accounting beta mempunyai hubungan yang signifikan dengan beta pasar. Sementara penelitian Lili menghasilkan bahwa hanya asset size yang berpegaruh signifikan, penelitian Franky Wijono menghasilkan hanya debt to common equity yang secara parsial berpengaruh terhadap beta saham, dan pada penelitian Kathleen C Mc Shane, variabel asset growth signifikan pada level of confidence $85 \%$.

Fakta lain yang ditemukan adalah dari beberapa penelitian di Bursa Efek Indonesia, yang mengambil sampel perusahaan listing di BEI dengan kurun waktu penelitian antara tahun 2004 hingga tahun 2011, hasil penelitiannya menunjukan bahwa faktor fundamental keuangan perusahaan tidak secara signifikan berpengaruh terhadap beta saham. Beberapa kesimpulan penelitian sebelumnya di BEI menyatakan bahwa penyebab kemungkinan tidak signifikannya pengaruh faktor fundamental keuangan terhadap beta saham adalah karena periode penelitian yang meliputi masa krisis ekonomi. Sedangkan penelitian Andriani, ternyata juga memberikan kesimpulan yang sama yaitu tidak signifikannya pengaruh faktor fundamental keuangan terhadap beta saham di Bursa Efek Indonesia.

Berdasarkan serangkaian latar belakang yang telah dikemukakan, dapat dirumuskan 3 inti permasalahan yang ingin dijawab pada penelitian ini, yaitu:

1. Apakah variabel Debt to common equity ratio, leverage, liquidity, Asset size, dan Asset growth, secara bersama-sama mempunyai pengaruh yang signifikan terhadap beta saham pada perusahaan Manufaktur di Bursa Efek Indonesia?

2. Di antara variabel-variabel Debt to common equity ratio, leverage, liquidity, Asset size, dan Asset growth, variabel manakah yang mempunyai pengaruh paling signifikan terhadap beta saham pada perusahaan Manufaktur Bursa Efek Indonesia?

3. Apakah variabel-variabel Debt to common equity ratio, leverage, liquidity, Asset size, dan Asset growth, mempunyai berpengaruh fundamental keuangan perusahaan?

\section{Kajian Literatur}

Saham merupakan bukti pemilikan sebagian dari perusahaan (Andriani, 2007) atau dapat didefinisikan juga sebagai tanda bukti kepemilikan atau penyertaan pemegangnya atas perusahaan yang mengeluarkan saham tersebut (emiten) menurut Martono;2001. Saham merupakan salah satu surat berharga yang paling banyak diminati oleh para investor karena saham dapat memberikan return yang lebih tinggi dibanding surat berharga lainnya. Selain memberikan return yang tinggi, saham perusahaan yang go-publik sebagai komoditi investasi tergolong beresiko tinggi. Sifat komoditinya sangat peka terhadap perubahanperubahan yang terjadi, baik perubahan di luar negeri maupun di dalam negeri, perubahan di bidang politik, ekonomi, moneter, undangundang, maupun perubahan yang terjadi di dalam industri dan perusahan itu sendiri. Salah indikator utama yang menggambarkan pergerakan saham adalah indeks harga saham.

Sebagai sumber informasi bagi konsumen pasar modal mengenai harga saham, setiap kurun waktu tertentu Bursa Efek Jakarta mengeluarkan informasi mengenai beberapa indeks saham yang diperdagangkan yaitu Indeks Harga Saham Gabungan atau dikenal pula dengan istilah composite index, menggunakan semua saham tercatat sebagai komponen penghitungan indeks. Indeks sektoral yang meggunakan semua saham yang termasuk dalam masingmasing sektor. Indeks LQ 45 yang menggunakan 45 saham yang terpilih setelah melalui beberapa macam seleksi dan termasuk dalam saham blue chips. Jakarta Islamic Index yang menggunakan 30 saham yang masuk dalam kriteria syariah dan termasuk saham liquid. Indeks individual yaitu indeks harga masing-masing saham terhadap harga dasarnya.

Untuk dapat menjual saham perusahaan kepada masyarakat atau sering dikenal dengan 
go publik, perusahaan perlu melakukan persiapan internal dan penyiapan dokumentasi sesuai dengan persyaratan untuk go publik atau penawaran umum, serta memenuhi semua persyaratan yang ditetapkan BAPEPAM-LK. Penawaran Umum atau sering pula disebut Go Public adalah kegiatan penawaran saham atau Efek lainnya yang dilakukan oleh Emiten (perusahaan yang akan go public) untuk menjual saham atau Efek kepada masyarakat berdasarkan tata cara yang diatur oleh UU Pasar Modal dan Peraturan Pelaksanaannya.

Penawaran umum mencakup kegiatankegiatan berikut:

1. Periode Pasar Perdana yaitu ketika Efek ditawarkan kepada pemodal oleh Penjamin Emisi melalui para Agen Penjual yang ditunjuk

2. Penjatahan Saham yaitu pengalokasian Efek pesanan para pemodal sesuai dengan jumlah Efek yang tersedia;

3. Pencatatan Efek di Bursa, yaitu saat Efek tersebut mulai diperdagangkan di Bursa.

Proses Penawaran Umum saham dapat dikelompokkan menjadi 4 (empat) tahapan berikut:

1. Tahap Persiapan

Tahapan ini merupakan tahapan awal dalam rangka mempersiapkan segala sesuatu yang berkaitan dengan proses Penawaran Umum. Pada tahap yang paling awal perusahaan yang akan menerbitkan saham terlebih dahulu melakukan Rapat Umum Pemegang Saham (RUPS) untuk meminta persetujuan para pemegang saham dalam rangka Penawaran Umum saham. Setelah mendapat persetujuan, selanjutnya emiten melakukan penunjukan penjamin emisi serta lembaga dan profesi penunjang pasar yaitu:

a. Penjamin Emisi (underwriter). Merupakan pihak yang paling banyak keterlibatannya dalam membantu emiten dalam rangka penerbitan saham. Kegiatan yang dilakukan penjamin emisi antara lain: menyiapkan berbagai dokumen, membantu menyiapkan prospektus, dan memberikan penjaminan atas penerbitan. b. Akuntan Publik (Auditor Independen). Bertugas melakukan audit atau pemeriksaan atas laporan keuangan calon emiten.

c. Penilai untuk melakukan penilaian terhadap aktiva tetap perusahaan dan menentukan nilai wajar dari aktiva tetap tersebut;

d. Konsultan Hukum untuk memberikan pendapat dari segi hukum (legal opinion).

e. Notaris untuk membuat akta-akta perubahan Anggaran Dasar, akta perjanjian-perjanjian dalam rangka penawaran umum dan juga notulennotulen rapat.

2. Tahap Pengajuan Pernyataan Pendaftaran Pada tahap ini, dilengkapi dengan dokumen-dokumen pendukung calon emiten menyampaikan pendaftaran kepada BAPEPAM-LK hingga BAPEPAM-LK menyatakan Pernyataan Pendaftaran menjadi Efektif.

3. Tahap Penawaran Saham

Tahapan ini merupakan tahapan utama, karena pada waktu inilah emiten menawarkan saham kepada masyarakat investor. Investor dapat membeli saham tersebut melalui agen-agen penjual yang telah ditunjuk. Masa Penawaran sekurangkurangnya tiga hari kerja. Perlu diingat pula bahwa tidak seluruh keinginan investor terpenuhi dalam tahapan ini. Misal, saham yang dilepas ke pasar perdana sebanyak 100 juta saham sementara yang ingin dibeli seluruh investor berjumlah 150 juta saham. Jika investor tidak mendapatkan saham pada pasar perdana, maka investor tersebut dapat membeli di pasar sekunder yaitu setelah saham dicatatkan di Bursa Efek.

4. Tahap Pencatatan saham di Bursa Efek Setelah selesai penjualan saham di pasar perdana, selanjutnya saham tersebut dicatatkan di Bursa Efek Indonesia.

Resiko sistematis sebuah saham dapat diukur dengan melihat berubahnya return pasar. Besarnya perubahan return saham 
terhadap return pasar direflesikan oleh koefesien beta saham tersebut. Beta merupakan suatu pengukur volatilitas return suatu sekuritas atau return portofolio terhadap return pasar. Volatilitas adalah fluktuasi dari return suatu sekuritas atau portofolio dalam suatu periode waktu tertentu. Brealy, Myers and Marcus memberi definisi sebagai berikut:

"Risk depends on exposure to macroeconomics events and can be measured as the sensitivity of a stock's return to fluctuations in returns on the market portfolio. This sensitivity is called the stock's beta. (Andriani, 2007)

Menurut Eugene F.Brigham dan Joel F.Houston, koefesien beta adalah kecenderungan saham untuk bergerak naik atau turun dalam pasar. Menurut definisinya, saham yang mempunyai beta sebesar 1.0 mengindikasikan bahwa secara umum jika pasar bergerak ke atas 10 persen, maka saham juga akan naik sebesar 10 persen, sementara jika pasar turun 10 persen, maka saham juga akan turun 10 persen. Portofolio saham dengan $B=1.0$ akan bergerak naik dan turun sesuai dengan rata-rata pasar, dan akan memiliki resiko yang sama dengan rata-rata pasar. Jika $\beta=0.5$ maka perubahan saham hanya separuh dari perubahan pasar. Sedangkan jika $\beta=2.0$, maka perubahan saham akan dua kali lipat dari perubahan ratarata saham.

Jadi dapat disimpulkan bahwa apabila suatu saham lebih kecil dari 1 maka gejolak harga saham tersebut lebih lemah atau lebih rendah dari pada gejolak pasar, sedangkan apabila beta saham sama dengan 1 maka gejolak harga saham bersangkutan sama dengan gejolak indeks pasar. Jika gejolak harga saham searah maka beta saham positif sedangkan jika gejolak harga berlawanan maka beta saham negatif.

Mengutip dari Jogiyanto "Beta suatu sekuritas dapat dihitung dengan teknik estimasi yang menggunakan data historis. Beta yang dihitung berlandaskan data historis ini selanjutnya dapat digunakan untuk mengestimasi beta masa datang. Bukti-bukti empiris menunjukan bahwa beta historis mampu menyediakan informasi tentang beta masa depan." Beta yang dihitung dengan data pasar disebut dengan beta pasar. Beta yang dihitung dengan data akuntansi disebut beta akuntansi, dan beta yang dihitung dengan data fundamental disebut dengan beta fundamental.

Dalam penelitian ini beta yang dipergunakan adalah beta pasar, beta pasar dapat diestimasi dengan mengumpulkan nilai-nilai historis return dari sekuritas dan dari retur pasar selama periode tertentu. Dengan menggunakan teknik regresi, return sekuritas sebagai variabel dependen dan return pasar sebagai variabel independen, beta suatu sekuritas dapat diestimasi. Persamaan regresi yang digunakan untuk mengestimasi beta dapat didasarkan pada model Indeks Tunggal (single-index model) atau CAPM (Capital Asset Pricing Model).

Menurut Tandelilin jika menggunakan model indeks tunggal atau model pasar, beta dapat dihitung berdasarkan persamaan sebagai berikut :

$\mathrm{R}_{\mathrm{i}}=\alpha_{\mathrm{i}}+\beta \mathrm{iRM}+\mathrm{ei}$

$\mathrm{R}_{\mathrm{i}}=$ return saham $\mathrm{i}$

$\alpha_{i}=$ expected return saham i jika $R_{M}=0$

$\beta_{\mathrm{i}}=$ beta saham $\mathrm{i}$

$\mathrm{RM}=$ return pasar

$e_{i}=$ pengaruh dari firm-specific events

Pada umumnya ada dua teknik yang digunakan para analis keuangan dan investor untuk pengambilan keputusan investasinya, yaitu analisis teknikal dan analisis fundamental. Analisis teknikal adalah suatu teknik keputusan semata-mata hanya melihat kecenderungan suatu kejadian tanpa memperhatikan faktor-faktor penyebabnya. Biasanya teknik ini menggunakan grafik sebagai analisatornya. Keuntungan penggunaan analisis teknikal tidak terlepas dari asumsi-asumsi yang dianut oleh para analisi teknikal. Dengan analisis teknikal investor dapat mengakses informasi secara cepat sehingga apabila investor tersebut mempunyai kemampuan analitis yang tinggi dan punya insting yang tajam atas apa yang akan terjadi terhadap harga pasar, dan menerjemahkan informasi tersebut ke dalam tindakan membeli atau menjual saham maka 
investor tersebut akan mampu mendapatkan return abnormal yang melebihi return pasar dan investor lainnya. Disamping keuntungan tersebut analisis teknikal juga memiliki kelemahan terutama berkaitan dengan asumsi yang mendasarinya dan keefektifan pendekatan analisis teknikal dalam memprediksi harga saham, harga saham secara statistik tidak bergerak mengikuti trend. Selain itu dengan banyaknya investor yang melakukan analisa teknikal dalam pengambilan keputusan terhadap informasi baru yang memasuki pasar, maka tentu saja kecepatan penyesuaian harga akan menjadi lebih cepat dari biasanya, jika ini terjadi, dalam jangka panjang keefektifan penggunaan analisis teknikal barangkali sudah tidak akan bermanfaat lagi.

Sebaliknya teknik fundamental mencoba mempelajari hubungan antara suatu kejadian dengan kondisi fundamentalnya. Faktor fundamental keuangan perusahaan utamanya dapat diperoleh dari data historis laporan keuangan perusahaan yaitu neraca, laporan laba rugi, dan laporan perubahan modal. Keuntungan dari teknik fundamental adalah dapat memberikan informasi bagi investor tentang kondisi perusahaan, termasuk pertumbuhan dan prospek di masa yang akan datang, hasil analisis fundamental akan membantu investor dalam menentukan layak atau tidaknya suatu saham yang diterbitkan perusahaan untuk dijadikan alternatif investasi. Sedangkan kelemahannya adalah memerlukan ketepatan dan waktu yang lebih lama dibanding penggunaan data-data pasar, di samping itu penggunaan informasi earning multiplier dalam analisis fundamental bersifat subyektif bagi investor yang berbeda.

Banyak faktor fundamental keuangan yang dapat dianalisis untuk kepentingan seorang analis, terutama dalam bentuk rasiorasio di antaranya adalah rasio likuiditas, profitabilitas, aktivitas, dan leverage, dan lainlain, beberapa diantaranya akan dibahas disini adalah yang berhubungan dengan penelitian ini.

1. Debt to common equity

Rasio ini untuk menilai batasan perusahaan yang digunakan perusahaan dalam meminjam uang Menurut Riyanto, rasio ini adalah perbandingan antara jumlah pinjaman yang diberikan para kreditur, baik jangka panjang atau jangka pendek dengan modal sendiri (James and John, 1995). Debt to to common equity dapat didefinisikan sebagai perbandingan antara total hutang dengan modal sendiri (Riyanto, 2002). Rasio ini mengukur seberapa besar perusahaan mendanai operasionalnya dengan hutang. Semakin besar rasio ini semakin besar porsi hutang dalam struktur modal perusahaan ini. Porsi hutang yang besar dalam struktur modal suatu perusahaan dapat mencerminkan tingkat resiko tinggi karena adanya kemungkinan perusahaan tersebut tidak dapat memenuhi kewajibannya membayar bunga pinjaman. Besar kecilnya resiko ini dapat tercermin dari pergerakan harga sahamnya yang berfluktuasi.

Debt to common equity dapat dirumuskan menurut James and John sebagai berikut:

Debt to Common Equity $=\frac{\text { Total Kewajiban }}{\text { Modal Saham }}$

Sebagai contoh nilai debt to common equity $=0,81$, ini artinya pemberi pinjaman menyediakan 81 sen pendanaan untuk setiap Rp. 1 yang disediakan oleh pemegang saham. Semakin rendah rasio ini, maka semakin tinggi tingkat pendanaan perusahaan yang disediakan oleh pemegang saham. Diprediksikan bahwa rasio ini mempunyai hubungan yang searah dengan beta saham, semakin besar nilai rasio ini maka akan semakin besar nilai beta.

\section{Leverage}

Rasio ini berguna untuk menunjukkan kualitias kewajiban perusahaan serta berapa besar perbandingan antara kewajiban tersebut dengan akitva perusahaan yang terbagi dalam rasio utang. Menurut Riyanto, rasio leverage yaitu rasio yang mengukur hingga sejauh mana perusahaan dibiayai oleh hutang (Riyanto, 2007). Rasio leverage mengukur dimana perbandingan antara dana yang disediakan perusahaan dengan dana yang berasal dari kredit perusahaan. Eugene F Brigham dan Joel F Houston mengklasifikasikan 
leverage menjadi dua jenis yaitu leverage operasi dan leverage keuangan. Leverage bisnis berkaitan dengan resiko bisnis sedangkan leverage keuangan berhubungan dengan resiko keuangan. Resiko bisnis yaitu tingkat resiko dari aktiva perusahaan jika tidak menggunakan utang. Jika sebagian besar dari total biaya perusahaan adalah biaya tetap, perusahaan itu dikatakan mempunyai leverage operasi yang tinggi. Leverage keuangan mengacu pada penggunaan sekuritas yang memberikan penghasilan tetap yaitu utang dan saham preferen dan resiko keuangan adalah tambahan resiko bagi pemegang saham biasa akibat penggunaan leverage keuangan. Pembiayaan dengan utang umumnya akan memperbesar tingkat pengembalian yang diharapkan untuk suatu investasi, tetapi utang juga memperbesar tingkat resiko investasi bagi pemilik perusahaan, yaitu para pemegang saham biasa. Meskipun penggunaan leverage keuangan meningkatkan ROE yang diharapkan, namun leverage keuangan juga meratakan distribusi probabilitas dan meningkatkan probabilitas terjadinya kerugian, sehingga menambah resiko yang ditanggung pemegang saham. Berikut adalah kutipan dari Charles Gibson dalam buku Riyanto mengenai leverage keuangan.

"fluctuations in the firm's business have a greater impact to equity returns when firms are leveraged because the debtholders have first claim on the firms revenue and assets. Therefore, fiancial leverage makes the rate of return on equity riskier."

Dari pendapat tersebut dapat disimpulkan bahwa leverage menunjukan nilai aktiva dan pendapatan yang digunakan untuk menutupi hutang perusahaan. Hal ini mengakibatkan leverage menjadi salah satu ukuran bahwa perusahaan tengah menghadapi resiko akibat hutang yang dimilikinya. Leverage diprediksi mempunyai hubungan positif dengan beta, semakin besar nilai leverage maka akan semakin besar nilai beta menurut James and John dapat dirumuskan sebagai berikut:

$$
\text { Leverage }=\frac{\text { Total Kewajiban }}{\text { Total Aktiva }}
$$

Sebagai contoh nilai Leverage $=0,45$, ini artinya $45 \%$ dari aktiva perusahaan didanai oleh hutang, sedangkan $55 \%$ pendanaan berasal dari ekuitas pemegang saham. Secara teoritis jika perusahaan sekarang dilikuidasi, aktiva dapat dijual paling sedikit seharga 45 sen dari setiap Rp. 1 sebelum pemberi pinjaman menanggung kerugian.

3. Likuiditas

Likuiditas adalah kemampuan perusahaan dalam memenuhi kewajiban jangka pendeknya. Ada beberapa rasio yang termasuk dalam rasio likuiditas diantaranya current ratio, quick ratio, dan acid test ratio. Semakin besar rasio ini maka semakin baik artinya posisi perusahaan dalam keadaan likuid yaitu aktiva lancarnya mampu memenuhi kewajiban jangka pendeknya seandainya perusahaan tersebut harus dilikuidasi.

Rasio lancar atau current ratio dihitung dengan membagi aktiva lancar dengan kewajiban lancar. Aktiva lancar umumnya terdiri kas, surat berharga, piutang dagang dan persediaan sedang kewajiban lancar terdiri dari hutang dagang, wesel bayar jangka pendek, hutang jangka panjang yang akan segera jatuh tempo, pajak penghasilan yang terhutang, dan bebanbeban lain yang terutang. Rasio lancar merupakan ukuran yang paling umum digunakan untuk mengetahui kesanggupan memenuhi kewajiban jangka pendek. Rasio tersebut menunjukan seberapa jauh tuntutan dari kreditor jangka pendek akan dipenuhi oleh aktiva yang diperkirakan menjadi uang tunai dalam periode yang sama dengan waktu jatuh tempo hutang.

Quick ratio atau acid test ratio atau rasio cepat dihitung dengan mengurangkan persediaan dari aktiva lancar kemudian dibagi dengan kewajiban lancar. Persediaan merupakan unsur aktiva lancar yang paling tidak likuid dan seringkali 
merupakan kerugian jika terjadi likuidasi. Oleh karena itu, rasio cepat merupakan ukuran penting untuk mengetahui kemampuan perusahaan memenuhi kewajiban jangka pendeknya tanpa memperhitungkan penjualan persediaan.

Likuiditas diprediksi mempunyai hubungan yang negatif dengan beta, menurut James and John karena semakin likuid perusahaan, semakin kecil resikonya.

Likuiditas $=\frac{\text { Aktiva Lancar }}{\text { Hutang Lancar }}$

Sebagai contoh nilai Liqudity $=2,5$, ini artinya kewajiban jangka pendek sebesar Rp. 1 ditanggung atau dijamin dengan aktiva lancar sejumlah Rp. 2,5.

\section{Asset Size}

Asset Size adalah ukuran perusahaan atau besarnya perusahaan yang diukur dengan besarnya nilai aktiva secara keseluruhan atau asset total perusahaan.

Variabel ini diprediksi mempunyai hubungan yang negatif dengan beta saham, dengan anggapan perusahaan yang besar dianggap mempunyai resiko yang lebih kecil dibandingkan dengan perusahaan yang lebih kecil, ini didasarkan karena perusahaan yang besar lebih mempunyai akses ke pasar modal. Sedangkan menurut jogiyanto dapat dirumuskan sebagai berikut

Asset size $=$ Logaritma $($ Total asset perusahaan)

\section{Asset Growth}

Asset growth didefnisikan sebagai perubahan (tingkat pertumbuhan) tahunan dari aktiva total. Variabel ini diasumsikan mempunyai hubungan positif dengan beta, hubungan ini tidak didukung oleh teori.

James and John merumuskan sebagai berikut :

"Natural log of the ratio of total asset at the end of the selected time period to total asset at the beginning of the period, divided by the number of years in the period"

Asset Growth $=\log \left(\frac{\text { Aset Total Akhir Periode }}{\text { Aset Total Awal Periode }}\right)$

Berdasarkan pada serangkaian teori yang telah dikemukakan, maka dalam melaksanakan penelitian ini, kerangka konseptual yang diajukan adalah sebagaimana terlihat pada gambar 1 .

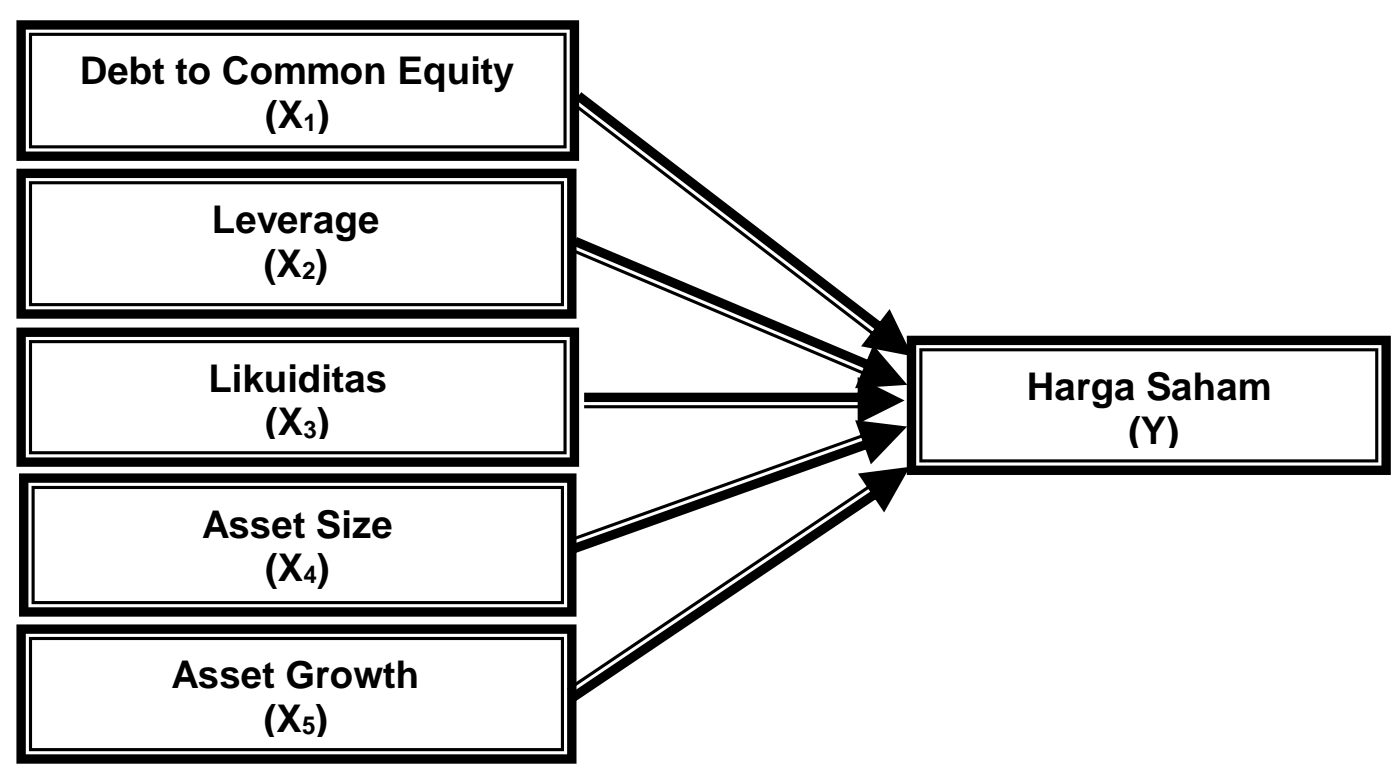

Gambar 1. Kerangka Konseptual Penelitian 
Berdasarkan rumusan masalah dan tujuan penelitian, maka dapat selanjutnya dikemukakan hipotesis dalam penlitian ini, di mana seperti diketahui bahwa hipotesis adalah jawaban sementara terhadap suatu permasalahan yang perlu dibuktikan kebenarannya (Sugiyono, 2005:68). Hipotesis pada penelitian ini adalah:

1. Terdapat pengaruh yang signifikan secara bersama-sama dari faktor fundamental variabel debt to common equity ratio, leverage, liquidity, asset size, dan asset growth terhadap beta saham pada perusahan manufaktur di Bursa Efek Indonesia.

2. Variabel leverage memberikan pengaruh yang signifikan terhadap beta saham pada perusahaan manufaktur di Bursa Efek Indonesia.

3. Variabel liquidity mempunyai pengaruh fundamental keuangan perusahaan

\section{Metode Penelitian}

Variabel yang akan dianalisis dikelompokkan menjadi dua bagian, yaitu variabel independen berupa variabel common debt to equity, leverage, liquidity, asset size, dan asset growth. Sedangkan variabel dependen adalah beta saham dari masingmasing perusahaan. Definisi operasional dari masing-masing variabel penelitian ini meliputi:

1. Debt to common equity, diperoleh dari perbandingan antara total hutang dengan modal saham, yang dihitung per tahun selama periode penilitian.

2. Leverage diperoleh dari perbandingan total kewajiban dengan total aktiva, yang dihitung per tahun selama periode penelitian

3. Liquidity diperoleh dari perbandingan aktiva lancar dengan hutang lancar, yang dihitung per tahun selama periode penelitian.

4. Asset size diperoleh dari logaritma dari total asset perusahaan yang dihitung per tahun selama periode penelitian.

5. Asset growth diperoleh dari logaritma dari rasio antara asset total perusahaan pada akhir periode dengan asset total perusahaan pada awal periode yang tercantum sebagai jumlah aktiva di neraca perusahaan, yang dihitung per tahun selama periode penelitian.

6. Beta saham yang diteliti adalah beta pasar yang diukur oleh penulis melalui regresi antara perubahan indeks individual saham dengan perubahan indeks harga saham. Beta diperoleh dengan teknik regresi yang mendasarkan pada model indeks tunggal, di mana variabel dependennya adalah perubahan indeks individual saham bulanan setiap perusahaan dengan mengambil harga saham pada setiap akhir bulan dan variabel independennya adalah perubahan indeks harga saham sektoral bulanan dengan mengambil nilai indeks harga saham pada setiap akhir bulan.

Persamaan regresi dari hasil penelitian ini direncanakan adalah sebagai berikut:

$r i=\alpha i+\beta i R u+e i$

Rumus return indeks saham individual untuk waktu ke-t menggunakan rumus sebagai berikut:

$R_{I H S I}=\frac{I H S I_{t}-I H S I_{t-1}}{I H S I_{t-1}}$

Rumus return indeks saham sektoral manufaktur untuk waktu ke-t menggunakan rumus sebagai berikut :

$R_{I H S m}=\frac{I H S m_{t}-I H S m_{t-1}}{I H S m_{t-1}}$

Jenis data yang digunakan pada penelitian ini adalah:

1. Data kualitatif adalah data yang tidak diwujudkan dengan angka-angka melainkan dalam bentuk penjelasan yang menggambarkan keadaan dan peristiwa tertentu.

2. Data Kuantitatif adalah data yang diberikan dalam bentuk angka yang lebih mudah diketahui ataupun untuk dibandingkan antar satu dengan yang lainnya.

Data yang diperlukan berupa data sekunder yaitu laporan keuangan perusahaan, pergerakan indek harga saham sektoral 
bulanan dan indeks harga saham individual bulanan perusahaan selama periode penelitian yang diterbitkan oleh Pihak Bursa Efek Indonesia (JSX Monthly Stastistic).

Populasi penelitian ini adalah sahamsaham yang termasuk dalam sektor usaha manufaktur di bursa efek Indonesia. Sedangkan yang menjadi sampel penelitian adalah perusahaan yang dipilih dengan memenuhi beberapa kriteria sebagai berikut :

1. Perusahaan-perusahaan manufaktur yang telah terdaftar di Bursa Efek Indonesia dan mengeluarkan Laporan Keuangan secara konstan dan berkelanjutan dari tahun 2009 sampai dengan tahun 2011.
2. Perusahaan yang akan dijadikan sampel penelitian harus memiliki kelengkapan data yang berkaitan dengan ke lima variabel yang telah ditentukan, pada tiap tahun selama periode pengujian

3. Dalam penelitian ini penulis mengambil 30 perusahaan manufaktur yang memenuhi kriteria tersebut di atas, dengan periode 8 tahun, sehingga jumlah sampel data yang diambil untuk penelitian ini sebanyak 240 sampel.

4. Perusahaan manufaktur yang menjadi sampel penelitian sebanyak 30 perusahaan, yang selengkapnya ditunjukkan pada Tabel 1 .

Tabel 1. Daftar Perusahaan Manufaktur yang Diteliti

\begin{tabular}{ccl}
\hline No & Kode Efek & \\
\hline 1. & ADES & PT. Ades Alfindo Putrasetia Tbk \\
\hline 2. & AKPI & PT. Argha Karya Prima Industry Tbk \\
\hline 3. & APLI & PT. Asiaplast Industries Tbk \\
\hline 4. & AQUA & PT. Aqua Golden Mississippi Tbk Dan Anak Perusahaan \\
\hline 5. & ARGO & PT. Agro Pantes Tbk Dan Anak Perusahaan \\
\hline 6. & ASII & PT. Astra International Tbk Dan Anak Perusahaan \\
\hline 7. & BATA & PT. Sepatu Bata Tbk \\
\hline 8. & BATI & PT. Bat Indonesia Tbk Dan Anak Perusahaan \\
\hline 9. & BRNA & PT. Berlina Tbk Dan Anak Perusahaan \\
\hline 10. & DPNS & PT. Duta Pertiwi Nusantara Tbk Dan Anak Perusahaan \\
\hline 11. & DLTA & PT. Delta Djakarta Tbk Dan Anak Perusahaan \\
\hline 12. & FASW & PT. Fajar Surya Wisesa Tbk Dan Anak Perusahaan \\
\hline 13. & GDYR & PT. Good Year Indonesia Tbk \\
\hline 14. & GGRM & PT. Gudang Garam Tbk Dan Anak Perusahaan \\
\hline 15. & GJTL & PT. Gajah Tunggal Tbk \\
\hline 16. & HMSP & PT. Hanjaya Mandala Sampoerna Tbk Dan Anak Perusahaan \\
\hline 17. & INDF & PT. Indofood Sukses Makmur Tbk Dan Anak Perusahaan \\
\hline 18. & INTP & PT. Indocement Tunggal Prakarsa Tbk Dan Anak Perusahaan \\
\hline 19. & KLBI & PT. Gt Kabel Indonesia Tbk \\
\hline 20. & KICI & PT. Kedaung Indah Cau Tbk Dan Anak Perusahaan \\
\hline 21. & KLBF & PT. Kalbe Farma Tbk Dan Anak Perusahaan \\
\hline 22. & LION & PT. Lion Metal Work Tbk Dan Anak Perusahaan \\
\hline 23. & MLIA & PT. Mulia Industrindo Tbk Dan Anak Perusahaan \\
\hline 24. & PAFI & PT. Panasia Filament Inti Tbk \\
\hline 25. & SMGR & PT. Semen Gersik (Persero) Tbk Dan Anak Perusahaan \\
\hline 26. & SULI & PT. Sumalindo Lestari Jaya Tbk Dan Anak Perusahaan \\
\hline 27. & TIRT & PT. Tirta Mahakam Resources Tbk Dan Anak Perusahaan \\
\hline 28. & TKIM & PT. Pabrik Kertas Tjiwi Kimia Tbk Dan Anak Perusahaan \\
\hline 30. & TSPC & PT. Tempo Scan Pacific Tbk Dan Anak Perusahaan \\
\hline & UNVR & PT. Unilever Indonesia Tbk Dan Anak Perusahaan \\
\hline 29 & \\
\hline 19
\end{tabular}


Dalam teknik pengumpulan data, penulis melakukan Periode pengamatan selama 8 tahun, mulai dari tahun 2004 sampai dengan tahun 2011, dengan melakukan Pengujian Hipotesis. Setelah hasil regersi linier berganda diketahui hasilnya, maka akan dilakukan uji analisi terhadap hipotesis yang ada, untuk hipotesis yang pertama akan dilakukan uji $\mathrm{F}$ dan untuk hipotesis kedua dengan menggunakan uji t. Uji hipotesis pertama yaitu menguji signifikan tidaknya pengaruh variabel bebas secara bersama-sama terhadap variabel tidak bebasnya, dengan uji $\mathrm{F}$, dengan kriteria seperti :

$\mathrm{H}_{0}=$ Koefisien regresi tidak signifikan $\mathrm{H}_{\mathrm{a}}=$ Koefisien regresi signifikan

Dasar pengambilan keputusan berdasarkan probabilitas significant $\mathrm{F}$ yaitu:

- Jika F sig > 0,05 maka Ho diterima dan Ha ditolak, berarti variasi dari model regresi linear berganda tidak mampu menjelaskan pengaruh variasi variabel bebas secara keseluruhan terhadap variabel tidak bebasnya.

- Jika F sih < 0.05 maka Ho ditolak dan Ha diterima berarti variasi dari model regresi linear berganda mampu menjelaskan pengaruh variasi variabel bebas secara keseluruhan terhadap variabel tidak bebasnya.

Uji hipotesis kedua yaitu menguji signifikan tidaknya pengaruh variabel bebas secara parsial terhadap variabel tidak bebas, dengan menggunakan uji t, dengan kriteria sebagai berikut :

Ho $=$ Koefisien regresi tidak signifikan $\mathrm{Ha}=$ Koefisien rergresi signifikan

Dasar pengambilan keputusan berdasarkan probabilitas signifikan t yaitu :

- Jika t sig > 0.05 maka Ho diterima dan Ha ditolak berarti tidak ada pengaruh variabel bebas secara parsial tehadap variabel terikatnya.

- Jika t hitung < 0.05 tabel maka Ho ditolak dan $\mathrm{Ha}$ diterima berarti ada pengaruh variabel bebas secara parsial tehadap variabel terikatnya.
Untuk mengetahui seberapa besarnya pengaruh variabel faktor fundamental keuangan perusahaan secara bersama-sama terhadap beta saham dapat diketahui dari besarnya koefesien determinasi berganda $\left(\mathrm{R}^{2}\right)$. Jika $\mathrm{R}^{2}$ diperoleh dari hasil perhitungan semakin tinggi, maka dapat dikatakan bahwa pengaruh faktor fundamental keuangan secara bersama-sama terhadap beta saham semakin tinggi atau semakin signifikan. Demikian juga sebaliknya jika $\mathrm{R}^{2}$ rendah maka dapat dikatakan bahwa pengaruh faktor fundamental keuangan terhadap beta saham tidak signifikan.

Uji asumsi klasik dilakukan untuk mengetahui apakah model yang ada dapat dilanjutkan analisisnya atau tidak. Agar model dapat dianalisis dan memberikan hasil yang representative maka model tersebut harus dapat memenuhi asumsi dasar klasik yaitu tidak terjadi gejala multikolinearitas, autokorelasi dan heteroskedastisitas. Pemilihan model terbaik dengan menggunakan analisis regresi linear berganda harus memenuhi beberapa asumsi klasik. Asumsi klasik yang akan diperiksa adalah asumsi adanya gejala multikoliniearitas, heteroskedastisitas, autokorelasi dan asumsi normalitas. Deteksi terhadap asumsi-asumsi klasik tersebut dapat dijelaskan sebagai berikut :

1. Uji multikolinearitas

Multikolinearitas merupakan suatu keadaaan di mana telah terjadi korelasi yang sangat kuat antar masing-masing variabel bebas. Akibat yang muncul jika sebuah model regresi memiliki kasus multikolinearitas adalah kesalahan standar estimasi akan cenderung meningkat dengan bertambahnya variabel bebas yang masuk pada model, sehingga signifikasi yang digunakan akan menolak hipotesis nol semakin besar. Akibatnya model yang diperoleh tidak valid untuk menaksir variabel independent. Salah satu cara untuk mendeteksi adanya kasus multikolinearitas ini adalah dengan melihat nilai variance inflating factor (VIF). Apabila nilai VIF suatu model kurang dari 10, maka model tersebut dinyatakan bebas dari kasus multikolinearitas. 
2. Uji heteroskesdastisitas

Heteroskesdastisitas artinya varians variabel dalam model tidak sama. Konsekuensi adanya heteroskesdastisitas dalam model regresi adalah penaksir (estimator) yang diperoleh tidak efisien, baik dalam sampel kecil maupun sampel besar. Salah satu yang dapat digunakan untuk melihat adanya kasus heteroskesdastisitas adalah dengan melihat pada gambar diagram scatter plot. Model penelitian yang tidak menunjukan gejala heteroskesdastisitas akan memberikan gambar yang menyebar dengan acak, tidak berkumpul pada satu titik, tidak membentuk satu pola tertentu misalnya model bergelombang atau model melingkar, dan yang terakhir berada di atas dan dibawah angka nol (tersebar pada nilai positif dan negatif).

3. Uji autokorelasi

Autokorelasi artinya adanya korelasi antara anggota, serangkaian observasi yang diurutkan menurut waktu (seperti dalam deretan waktu) atau ruang (seperti dalam data cross sectional).

Kriteria Pengujian autokorelasi ditunjukan dalam tabel durbin watson, apabila durbin watson statistik semakin mendekati 2 maka tidak terdapat gejala autokorelasi, tetapi jika mendekati nol, maka menunjukkan bahwa terdapat autokorelasi yang positif. Apabila nilai durbin watson mendekati angka 4, maka terdapat petunjuk adanya autokorelasi negatif.

Konsekuensi dari adanya autokorelasi dalam model regresi adalah model yang dihasilkan tidak dapat digunakan untuk menaksir variabel dependen pada nilai variabel independent tertentu.

\section{d. Uji Normalitas}

Uji normalitas diperlukan untuk mengetahui apakah error dari model regresi berdistribusi normal atau tidak. Error dari model regresi yang terbentuk harus memenuhi asumsi normalitas ini. Jika error model regresi tidak secara normal, maka statistik uji apakah itu uji $t$ maupun uji F tidak bisa diterapkan. Salah satu cara untuk mendeteksi apakah error model regresi berdistribusi normal atau tidak adalah dengan memperhatikan probability plot residual. Jika probability plot residual berada di sekitar garis horizontal, maka error dari model tersebut dikatakan berdistribusi secara normal.

Sesuai variabel penelitian yang lebih dari satu variabel bebas, maka model analisis yang digunakan dalam penelitian ini adalah berbentuk Regresi Linear Berganda (Multiple Regression Linear). Analisis ini digunakan untuk mengetahui hubungan variabel bebas terhadap variabel terikat.

Langkah-langkah dalam penelitian:

1. Menentukan beta masing-masing saham perusahaan yang diteliti untuk tahun 2004 sampai dengan tahun 2011. Untuk mencari beta masing-masing saham yang diteliti digunakan teknik regresi sederhana dengan variabel dependennya adalah return (perubahan) bulanan indeks saham yang bersangkutan (individual) dan variabel dependennya adalah return bulanan Indeks Harga Saham Sektoral Manufaktur.

2. Menentukan nilai-nilai faktor fundamental, dari data keuangan masing-masing perusahaan, sesuai dengan rumusan yang telah dijelaskan diatas.

3. Beta masing-masing saham yang telah ditentukan pada poin satu kemudian diregresi dengan menggunakan model regresi linear berganda. Variabel dependennya adalah beta saham dan variabel independennya adalah variabel fundamental keuangan perusahaan. Model persamaan regresi yang digunakan adalah :

$$
\mathrm{Y}=\mathrm{bo}+\mathrm{b} 1 \mathrm{X} 1+\mathrm{b} 2 \mathrm{X} 2+\mathrm{b} 3 \mathrm{X} 3+\mathrm{b} 4 \mathrm{x} 4
$$$$
+\mathrm{b} 5 \mathrm{X} 5+\mathrm{e}
$$

Dimana:

$\mathrm{Y}=$ Beta Saham

$\mathrm{X} 1=$ debt to common equity

$\mathrm{X} 2$ = leverage

$\mathrm{X} 3$ = liquidity

$\mathrm{X} 4=$ asset size

$\mathrm{X} 5=$ asset growth

b1, b2, b3, b4 ,b5 = Koefisien Regresi

Parsial

bo $=$ intercept

$\mathrm{e}=$ Faktor Pengganggu (Residu) 
Alasan menggunakan metode ini adalah karena penelitian ini menggunakan lebih dari dua variabel independen. Selain itu penggunaan model regresi linear berganda juga untuk mengetahui pengaruh variabel independen terhadap variabel dependen, baik secara parsial maupun bersama-sama.

\section{Hasil Penelitian dan Pembahasan}

Sebelum melakukan analisis regresi, perlu terlebih dahulu dilakukan uji asumsi klasik, yang terdiri dari:

1. Pengujian Asumsi Multikolinearitas

Untuk mengetahui apakah terjadi korelasi antara masing-masing variabel bebas, maka diuji dengan melihat nilai Variance Inflation Factor (VIF). Nilai VIF pada penelitian ini untuk semua variabel kurang dari 10, maka dapat disimpulkan bahwa model regresi yang diajukan tidak menunjukkan adanya gejala multikolinearitas.

2. Pengujian Asumsi Heteroskesdastisitas Uji heteroskedastisitas artinya tidak terjadi korelasi antara variabel bebas dengan penggangggu (residual). Jika terjadi korelasi antara variabel bebas dengan residualnya, maka model menjadi tidak baik untuk estimasi (peramalan). Menurut asumsi ini tidak boleh terjadi korelasi yang cukup kuat antara variabel bebas dengan residualnya. Pada Gambar 2 Diagram scatter plot, dapat diketahui bahwa data menyebar sacara acak, tidak terbentuk satu pola tertentu, dan data juga tersebar di atas dan di bawah angka nol. Berarti dapat disimpulkan bahwa model bebas dari gejala heteroskedastisitas.

3. Pengujian Asumsi Autokorelasi

Salah satu cara untuk mendeteksi adanya kasus autokorelasi adalah dengan pengujian Durbin Watson (DW). Nilai Durbin Watson berdasarkan perhitungan dapat dilihat pada tabel 2 Model Summary adalah sebesar 1,942. nilai tersebut mendekati 2 dengan demikian dapat disimpulkan tidak terjadi gejala autokorelasi antara masing-masing variabel pengganggu.

\section{Dependent Variable: Beta Saham}

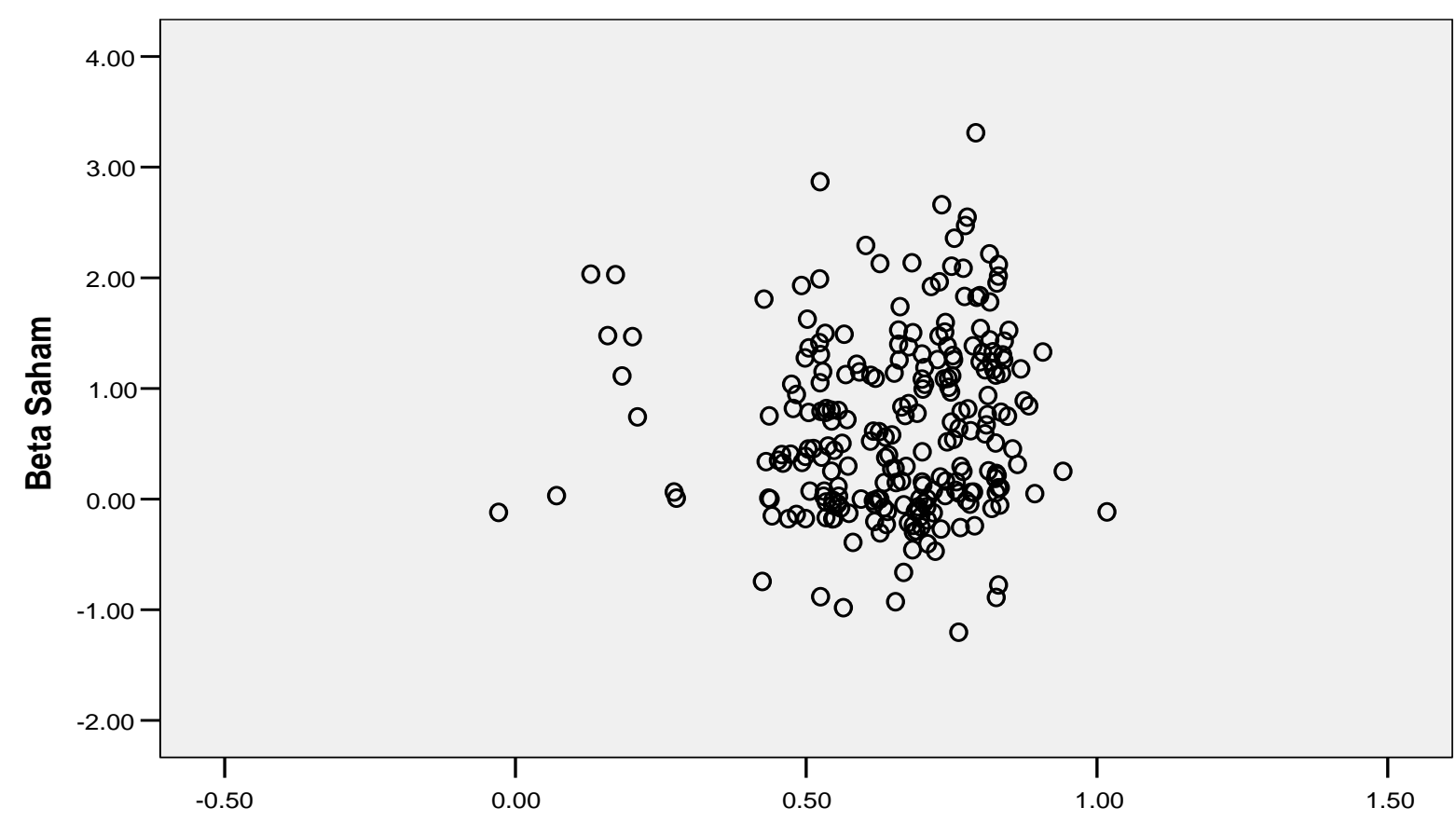

Regression Adjusted (Press) Predicted Value 
4. Pengujian Normalitas

Uji normalitas bertujuan untuk menguji apakah dalam model regresi, variabel tidak bebas dan variabel bebas keduanya mempunyai distribusi normal atau tidak. Model regresi yang baik adalah memiliki distribusi normal atau mendekati normal. Salah satu metode yang digunakan adalah dengan melihat grafik normal probability plot yang membandingkan distribusi kumulatif dari data sesungguhnya dan distribusi kumulatif dari distribusi normal. Distribusi normal akan membentuk satu garis lurus diagonal dan plotting data akan dibandingkan dengan garis diagonal. Jika garis yang menggambarkan data sesungguhnya mengikuti garis diagonalnya maka distribusi data dikatakan normal, dan sebaliknya jika terjadi penyimpangan data yang terlalu jauh dari garis normal, maka dapat disimpulkan bahwa data tidak memiliki distribusi normal. Dari hasil analisis yang ditunjukan pada gambar 3 Kurva Normal data bergerak disekitar kurva normal, maka dapat disimpulkan bahwa uji normalitas terpenuhi.

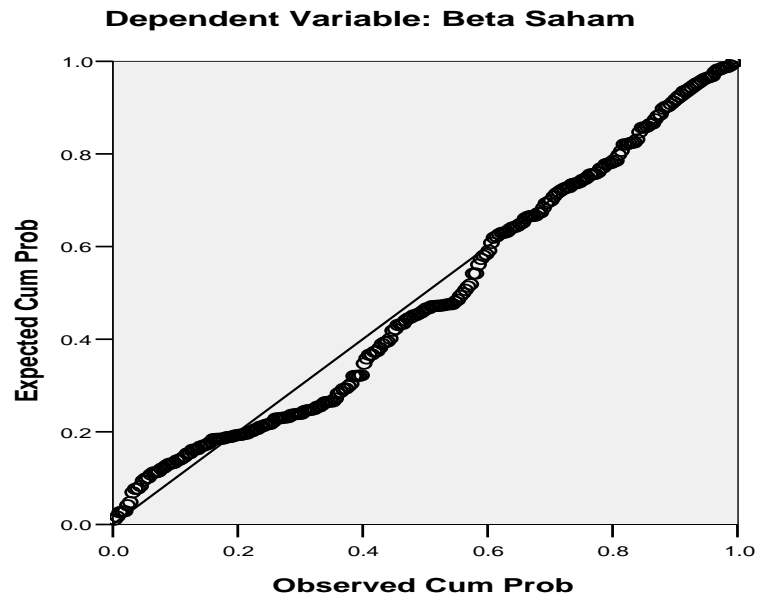

Gambar 3. Kurva Normal

Karena penelitian ini menggunakan lebih dari dua variabel independen maka analisa yang digunakan adalah analisa regresi liniear berganda yang dianalisis dengan program SPSS Versi 13.00, dari hasil analasis untuk menjawab hipotesis penelitian ini akan dilakukan uji statistik. Berdasarkan hasil analisis regresi linear berganda dengan menggunakan program SPSS Versi 13.00, diperoleh hasil yang ditampilkan pada Tabel 2, 3, dan 4 .

Tabel 2. Model Summary

\begin{tabular}{llllll}
\hline Model & R & R Square & $\begin{array}{l}\text { Adjusted R } \\
\text { Square }\end{array}$ & $\begin{array}{l}\text { Std. Error of } \\
\text { The Estimate }\end{array}$ & $\begin{array}{l}\text { Durbin- } \\
\text { Watson }\end{array}$ \\
\hline 1 & .193 & .037 & .017 & .79532 & 1,942 \\
\hline
\end{tabular}

Tabel 3. ANOVA

\begin{tabular}{lrrrrrr}
\hline Model & Sum of Squares & df & Mean Square & F & \multicolumn{2}{c}{ Sig } \\
\hline Regression & 5,757 & 5 & 1,151 & 1,820 & .110 \\
Residual & 148,014 & 234 & .633 & & \\
Total & 153,772 & 239 & & & & \\
\hline
\end{tabular}

\section{Tabel 4. Coefficients}

\begin{tabular}{lrrrrr}
\hline Model & \multicolumn{2}{c}{$\begin{array}{c}\text { Unstandardized } \\
\text { Coeficients }\end{array}$} & $\begin{array}{c}\text { Standardized } \\
\text { Coeficient }\end{array}$ & t & Sig \\
\cline { 2 - 4 } & \multicolumn{1}{c}{$\mathrm{B}$} & \multicolumn{1}{c}{ Std. Error } & \multicolumn{1}{c}{ Beta } & & \\
\hline (Constant & $-1,398$ &, 791 & & $-1,768$ &, 078 \\
Debt to Common Equity &,- 014 &, 008 &,- 118 & $-1,726$ &, 086 \\
Leverage &, 196 &, 170 &, 092 & 1,155 &, 249 \\
Liquidity &, 014 &, 034 &, 033 &, 419 &, 676 \\
Asset Size &, 163 &, 063 &, 175 & 2,577 &, 011 \\
Asset Growth &,- 231 &, 457 &,- 033 &,- 504 &, 614 \\
\hline
\end{tabular}


Hipotesis pertama dalam penelitian ini berisikan pernyataan bahwa Debt To Common Equity (X1), Leverage (X2), Liquidity (X3), Asset Size (X4), Asset Growth (X5) secara bersama-sama memberikan pengaruh yang signifikan terhadap beta saham. Untuk menjawab hipotesis tersebut maka dilakukan pengujian dengan uji $\mathrm{F}$, dasar pengambilan keputusan berdasarkan probabilitas significant $F$ yaitu :

$\mathrm{H} 0=$ Koefisien regresi tidak signifikan $\mathrm{Ha}=$ Koefisien rergresi signifikan

Dasar pengambilan keputusan berdasarkan probabilitas significant $\mathrm{F}$ yaitu:

- Jika F sig > 0,05 maka Ho diterima dan Ha ditolak berarti variasi dari model regresi linear berganda tidak mampu menjelaskan pengaruh variasi varibel bebas secara keseluruhan terhadap variabel tidak bebasnya.

- Jika F sig < 0.05 maka Ho ditolak dan Ha diterima berarti variasi dari model regresi linear berganda mampu menjelaskan pengaruh variasi varibel bebas secara keseluruhan terhadap variabel tidak bebasnya.

Pada tabel 3, dapat dilihat bahwa nilai $\mathrm{F}$ sebesar 1,820 dengan tingkat signifikasi 0,110 dengan demikian hipotesis pertama ditolak ( $\mathrm{F}$ sig > 0,05), variabel Debt To Common Equity (X1), Leverage (X2), Liquidity (X3), Asset Size (X4), Asset Growth (X5) secara bersama-sama tidak memberikan pengaruh yang signifikan terhadap beta saham, pada tingkat signifikasi 5\%. Hasil ini berbeda dengan hasil penelitian di luar negeri yang dilakukan oleh Beacer CS dan kathleen C Mc Shane, tetapi sama dengan hasil penelitian yang dilakukan di dalam negeri yaitu Lili, Franky Wijono, A. Zubaidi Indra dan Andriani, hal ini mungkin disebabkan perbedaan jumlah sampel penelitian dan rentang waktu penelitian, selain itu kemungkinan pula disebabkan karena perbedaan karekteristik perusahaan dan perdagangan saham antara di luar negeri dan di dalam negeri.
Hal ini sebenarnya sejalan dengan teori yang menjelaskan bahwa beta merupakan suatu ukuran sistematis (resiko eksternal), sementara variabel fundamental keuangan perusahaan atau disebut juga informasi keuangan internal perusahaan. Pada kenyataannya variabel eksternal paling mempengaruhi nilai beta saham, sedangkan variabel internal akan memberikan kontribusi yang kecil dalam menjelaskan nilai beta. Dalam prekateknya para investor lebih banyak menggunakan analisa teknikal dalam pengambilan keputusan membeli atau menjual saham, dengan menggunakan datadata pasar, investor hanya perlu mengidentifikasikan bagaimana kecenderungan pergerakan harga saham dan menentukan kapan waktu yang tepat untuk mengambil tindakan membeli atau menjual saham, untuk memanfaatkan waktu penyesuaian harga saham sehingga bisa memperoleh keuntungan. Dan seperti yang kita ketahui bahwa analisa fundamental mempunyai kelemahannya adalah memerlukan ketepatan dan waktu yang lebih lama dibanding penggunaan data-data pasar, di samping itu penggunaan informasi earning multiplier dalam analisis fundamental bersifat subyektif bagi investor yang berbeda.

Berdasarkan data laporan yang diperoleh, diketahui bahwa hampir 30\% sampai dengan $40 \%$ kepemilikan saham perusahaaan yang diteliti pemiliknya adalah masyarakat umum, yang ditenggarai bahwa sebagian besar adalah ibu-ibu rumah tangga yang hanya mengejar prestige dan para pegawai negeri sipil yang ingin mengalihkan asetnya, serta para masyarakat yang ingin mendapatkan keuntungan besar dalam sesaat. Kurangnya pemahaman mereka tentang pentingnya faktor fundamental perusahaan sebagai sebuah gambaran tentang kondisi perusahaan yang mereka jadikan investasi, menyebabkan mereka sering melakukan short selling karena faktor-faktor eksternal, seperti isu-isu ekonomi, kebijakan pemerintah, serta isu-isu politik, hal ini yang menyebabkan mengapa perdagangan saham di bursa efek jakarta sangat berfluktuatif.

Pengujian hipotesis kedua menggunakan uji t, untuk menjawab hipotesis yang telah diajukan bahwa diduga variabel 
leverage memberikan pengaruh paling dominan terhadap beta saham, dasar pengambilan keputusan berdasarkan probabilitas significant t yaitu :

- Jika t sig > 0.05 maka Ho diterima dan Ha ditolak berarti tidak ada pengaruh variabel bebas secara parsial tehadap variabel terikatnya.

- Jika t hitung < 0.05 tabel maka Ho ditolak dan Ha diterima berarti ada pengaruh variabel bebas secara parsial tehadap variabel terikatnya.

Pada tabel 4 yang berisi nilai Coefficient, diketahui bahwa nilai t sig untuk variabel leverage adalah 0,249 hal ini menunjukkan bahwa leverage tidak memberikan pengaruh yang signifikan terhadap beta saham, variabel yang memberikan pengaruh signifikan terhadap beta adalah asset size dengan tingkat signifikasi sebesar 0,011. Hal ini mungkin disebabkan karena karekteristik investor di indonesia, saham-saham perusahaan yang beraset besar merupakan tempat investasi yang besar bagi mereka, hal ini dapat dilihat dari adanya sektor LQ 45 dibursa efek indonesia, yang mana merupakan kategori untuk perusahaan yang besar, mapan, stabil, dan memiliki manajemen yang baik. Selain itu perilaku investor di indonesia dalam berinvestasi di saham lebih cenderung mengharapkan capital gain dari pada pembagian dividen, tanpa memperhatikan kondisi dari perusahaan tersebut.

Variabel Debt to common equity mempunyai hubungan yang negatif dengan beta dengan besar koefisien 0,014 dan tingkat signifikasi sebesar 0,086, ini menunjukkan adanya korelasi negatif yang tidak signifikan. Hasil penelitian ini sama dengan penelitian sebelumnya yaitu penelitian Franky Wijono, yang menghasilkan korelasi negatif tidak signifikan antara variabel debt to common equity dengan beta saham, hal ini berbeda dengan teori yang memprediksikan bahwa antara variabel debt to common equity berkorelasi positif dengan beta saham, dimana semakin tinggi nilai rasio ini maka semakin tinggi resiko yang dihadapi perusahaan, karena semakin banyak dana yang disediakan oleh pemberi pinjaman.
Seperti yang dijelaskan diatas karakteristik dari investor saham yang ada di Indonesia, kemungkinan menjadi faktor utama yang menyebabkan perbedaan antara hasil penelitian ini dengan teori yang ada.

Variabel Leverage mempunyai hubungan yang positif dengan beta saham dengan besar koefisien 0,196 dan tingkat signifikasi sebesar 0,249, ini menunjukkan adanya korelasi positif yang tidak signifikan. Hasil ini sesuai dengan teori yang memprediksikan bahwa variabel leverage berkorelasi positif dengan beta saham, leverage menunjukkan resiko yang sedang ditanggung perusahaan, semakin besar leverage maka semakin besar resiko yang dihadapi perusahaan.

Variabel Liquidity mempunyai hubungan yang positif dengan beta saham dengan besar koefisien 0,014 dan tingkat signifikasi sebesar 0,676, ini menunjukkan adanya korelasi positif yang sangat tidak signifikan. Hasil ini tidak sesuai dengan teori Yogianto yang memprediksikan bahwa variabel liquidity berkorelasi negatif dengan beta saham. Semakin kecil nilai liqudity maka semakin besar resiko yang dihadapi perusahaan.

Sama halnya dengan variabel debt to common equity karakteristik dari investor saham yang ada di Indonesia, kemungkinan menjadi faktor utama yang menyebabkan perbedaan antara hasil penelitian ini dengan teori yang ada.

Variabel Asset Size mempunyai hubungan yang positif dengan beta saham dengan besar koefisien 0,163 dan tingkat signifikasi sebesar 0,011, ini menunjukkan adanya korelasi positif yang sangat signifikan. Hasil ini tidak sesuai dengan teori yang memprediksikan bahwa variabel asset size berkorelasi negatif dengan beta sahaam, perusahaan yang besar dianggap mempunyai resiko yang lebih kecil dibandingkan dengan perusahaan yang lebih kecil, karena perusahaan yang besar dianggap lebih mempunyai akses ke pasar modal. Sehingga dianggap mempunyai beta yang kecil.

Seperti yang dijelaskan di atas bahwa perbedaan ini mungkin disebabkan karena karekteristik investor di indonesia, sahamsaham perusahaan yang beraset besar 
merupakan tempat investasi yang besar bagi mereka, hal ini dapat dilihat dari adanya sektor LQ 45 dibursa efek indonesia, yang mana merupakan kategori untuk perusahaan yang besar, mapan, stabil, dan memiliki manajemen yang baik, Selain itu investor dalam berinvestasi di saham lebih cenderung mengharapkan capital gain dari pada pembagian dividen.

Variabel Asset Growth mempunyai hubungan yang negatif dengan beta saham dengan besar koefisien 0,231 dan tingkat signifikasi sebesa 0,614, ini menunjukkan adanya korelasi negatif yang tidak sangat signifikan. Tidak ada teori yang menyatakan tentang hubungan positif atau negatif antara asset growth dengan beta saham, tetapi asumsi yang ada bahwa asset growth mempunyai hubungan yang positif dengan beta saham.

Koefesien determinasi digunakan untuk mengukur proporsi total variasi variabel terikat yang dapat dijelaskan oleh variabel bebas. Jika nilai koefesien determinasi $\left(\mathrm{R}^{2}\right)$ mendekati 0 , maka variabel bebas semakin lemah dalam menjelaskan pengaruhnya terhadap variabel terikatnya. Semakin besar nilai koefesien $\left(\mathrm{R}^{2}\right)$, menunjukan semakin besar pula variabel bebas tersebut dapat menjelaskan pengaruhnya terhadap varaibel terikat. Angka $\mathrm{R}^{2}$ sebesar 0.037 berarti bahwa $3,7 \%$ beta bisa dijelaskan oleh variabel debt to common equity, leverage, liquidity, asset size, dan asset growth. Sedangkan sisanya sebesar 96,7\% dijelaskan oleh sebab-sebab lain. Berarti variabel-variabel independen dalam penelitian ini hanya memberikan kontribusi sebesar 3,7\% dalam menjelaskan beta saham, masih ada variabel-variabel lain yang mempengaruhi nilai beta. Mengkaji dari penelitian-penelitian sebelumnya penambahan variabel independen yang masuk dalam kategori variabel fundamental keuangan perusahaan kemungkinan tidak akan memberikan hasil yang jauh berbeda. Seperti dijelaskan sebelumnya hal ini dikarenakan variabel fundamental keuangan adalah variabel internal yang secara teoritis tidak berpengaruh terhadap nilai beta dan perilaku investor di indonesia yang kurang memahami tentang faktor fundamental perusahaan, mereka lebih cenderung untuk berspekuliasi untuk memperoleh capital gain dari pada pembagian dividen, selain itu dalam penelitian ini beta yang dipergunakan merupakan kombinasi antara beta positif dan negatif, sehingga angka Angka $\mathrm{R}^{2}$ hanya sebesar 0.037 atau $3,7 \%$.

\section{Kesimpulan}

Berdasarkan hasil penelitian yang telah diuraikan sebelumnya dapat disimpulkan bahwa:

1. Berdasarkan uji $\mathrm{F}$ dengan tingkat signifikasi $0.005(\mathrm{p}<5 \%)$, debt to common equity (X1), leverage (X2), likuiditas (X3), asset size (X4), dan asset growth (X6) secara simultan tidak berpengaruh signifikan terhadap variabel dependennya beta saham. Variabel independen dalam penelitian ini secara bersama-sama mampu menerangkan variabel dependennya dengan determinasi sebesr $3,7 \%$ dan sisanya $96.7 \%$ diterangkan oleh variabel lain yang tidak dimasukan dalam model penelitian ini. Besarnya koefesien korelasi yang ditunjukan oleh nilai $\mathrm{R}=0.193$ memberi indikasi tidak adanya korelasi yang cukup erat antara kelima variabel independen dengan variabel dependennya.

2. Hasil uji secara parsial dari penelitian ini menunjukan bahwa :

a. Debt to common equity (X1) mempunyai pengaruh tidak signifikan terhadap beta saham. Hal ini ditunjukan dengan tingkat signifikan 0,086.

b. Variabel leverage (X2) mempunyai pengaruh tidak signifikan terhadap beta saham. Hal ini ditunjukan dengan tingkat signifikan 0,249

c. Variabel likuiditas (X3) mempunyai pengaruh tidak signifikan terhadap beta saham. Hal ini ditunjukan dengan tingkat signifikan 0,676

d. Variabel asset size (X3) mempunyai pengaruh signifikan terhadap beta saham. Hal ini ditunjukan dengan tingkat signifikan 0,011

e. Variabel asset growth (X5) mempunyai pengaruh tidak signifikan terhadap beta saham. Hal ini ditunjukan dengan tingkat signifikan 0,614

Berdasarkan nilai korelasi dan nilai thitung menunjukan bahwa variabel asset 
size mempunyai korelasi yang paling kuat terhadap beta saham pada perusahaan manufaktur di bursa Efek Jakarta.

3. Dalam prekateknya para investor lebih banyak menggunakan analisa teknikal dalam pengambilan keputusan membeli atau menjual saham, dengan menggunakan data-data pasar, investor hanya perlu mengidentifikasikan bagaimana kecenderungan pergerakan harga saham dan menentukan kapan waktu yang tepat untuk mengambil tindakan membeli atau menjual saham, untuk memanfaatkan waktu penyesuaian harga saham sehingga bisa memperoleh keuntungan. Dan seperti yang kita ketahui bahwa analisa fundamental mempunyai kelemahannya adalah memerlukan ketepatan dan waktu yang lebih lama dibanding penggunaan data-data pasar, di samping itu penggunaan informasi earning multiplier dalam analisis fundamental bersifat subyektif bagi investor yang berbeda. Hampir 30\% sampai dengan $40 \%$ kepemilikan saham perusahaaan yang diteliti pemiliknya adalah masyarakat umum, yang ditenggarai bahwa sebagian besar adalah ibu-ibu rumah tangga yang hanya mengejar prestige dan para pegawai negeri sipil yang ingin mengalihkan aset, serta para masyarakat yang ingin mendapatkan keuntungan besar dalam sesaat.

Dari hasil penelitian ini, dapat dikemukakan beberapa saran sebagai berikut:

1. Selain memberikan informasi keuangan yang akurat dan transparan, hendaknya perusahaan juga memperhatikan pada faktor eksternal yang mempengaruhi fluktuasi harga saham dan nilai beta saham, sehingga perusahaan dapat melakukan langkah-langkah dan mengambil kebijaksanaan yang lebih baik lagi yang sesuai dengan misi dan tujuan perusahaan.

2. Bagi Investor, Masyarakat umum pemilik saham, dan pemerintah :

a. Selain menggunakan analisa teknikal dalam pengambilan keputusan membeli atau menjual saham hendaknya investor dapat menjadikan faktor fundamental keuangan perusahaan dalam menentukan pilihan investasi sahamnya, tetapi perlu dicermati bahwa faktor fundamental keuangan ini tidak memberikan kontribusi besar dalam menentukan koefesien beta yang mencerminkan resiko perusahaan.

b. Perlunya wawasan tentang faktor fundamental keuangan perusahaan bagi masyarakat luas, untuk berinvestasi di saham pada sebuah emiten, karena faktor fundamental keuangan perusahaan memberikan gambaran tentang kondisi perusahaan, pertumbuhan perusahaan dan prospek di masa datang.

c. Selain itu saham bukanlah satu-satunya alternatif untuk investasi walaupun saham merupakan investasi yang memberikan return yang tinggi tetapi saham juga mempunyai resiko yang tinggi, masih ada alternatif investasi lain seperti obligasi, deposito, emas dan aset riil lainnya seperti tanah dan property. Sebagai bahan pertimbangan pemilihan investasi hendaknya masyarakat luas membandingkan antara return yang dihasilkan dari saham dengan bunga yang didapatkan dari obliagsi atau deposito, serta resiko yang akan dihadapi dari alternatif investasi tersebut.

d. Dan pemerintah hendaknya dapat meneliti kepemilikan saham yang dimiliki masyarakat umum karena ditenggarai saham merupakan alternatif pengalihan aset dan penghindaran pajak.

3. Untuk peneliti selanjutnya apabila ingin melanjutkan penelitian ini, hendaknya menghindari variabel yang identik dan beta yang diambil yang beta positif saja.

\section{DAFTAR PUSTAKA}

A.Zubaidi Indra, 2006. Analisis Pengaruh Faktor - Faktor Fundamental terhadap Resiko Sistematis Pada Perusahaan di Bursa Efek Jakarta. Lampung : Lampung University Library

Andriani, 2007. Analisis Pengaruh Faktor Fundamental Keuangan Perusahaan Terhadap Beta Saham Pada Perusahaan 
LQ 45 di Bursa Efek Jakarta. Samarinda : Mulawarman University Library

Bhuono Agung Nugroho, 2005. Strategi Jitu Memilih Metode Statistik Penelitian dengan SPSS. Yogyakarta : Penerbit Andi

Brealy, Marcus, Myers, 1995. Fundamental of Corporate Finance. Mc Graw Hill Series in Finance

Brigham E F aand J F. Houston, 2001. Manajemen Keuangan. Terjemahan edisi Kedelapan, Jakarta : Erlangga

Foster, George. 1986. Financial Statement Analysis. New Jersey : Prentice Hall International

Gujarati, D. (1995) Ekonometrika Dasar. Jakarta : Erlangga

Horne, Van and Wachowicz John M, Jr, 1997. Prinsip-prinsip Manajemen Keuangan Edisi Kesembilan Jakarta : Salemba Empat

Jogiyanto H.M. 1998 Teori Portofolio dan Analisis Investasi, Edisi Pertama, Yogyakarta : BPFE

Kathleen C. McShane, Relationship Between Fundamental Factors and Beta,
International Journal of Commerce and Management.www.crtc.gc.ca

Lind, Marchal, Wathen, 2008. Teknik-teknik Statistika dalam Bisnis dan Ekonomi Menggunakan Kelompok Data Global, Jakarta : Salemba Empat

Martono, D. Agus Harjito, 2001, Manajemen Keuangan, Yogyakarta : Ekonisia Kampus Fakutas Ekonomi UII

R. Agus Sartono, 2001. Manajemen Keuangan Teori dan Aplikasi, Edisi 4, Yogyakarta : BPFE

Riyanto, Bambang, 2005. Dasar - dasar

Pembelanjaan Perusahaan, Edisi 4, Yogyakarta : BPFE

Syahril Alhusin, 2003. Aplikasi Statistik Praktis dengan SPSS.10 for Windows. Yogyakarta : Graha Ilmu

Tandelilin, Eduardus, 2001. Analisis Investasi dan Manajemen Portofolio. Edisi Pertama. Yogyakarta

Weston J. Fred, Thomas E.Copeland, 1991. Manajemen Keuangan, Terjemahan. Edisi kedelapan. Jakarta : Erlangga

Bursa Efek Indonesia 